Address for Correspondence: Dr. Florence Van Ryckeghem, Department of Medical Oncology, Ghent University Hospital, Belgium.

Email: florence.vanryckeghem@ugent.be

\begin{tabular}{|c|}
\hline Access this article 0 \\
\hline $\begin{array}{l}\text { Website: } \\
\text { www.intern-med.com }\end{array}$ \\
\hline $\begin{array}{l}\text { DOI: } \\
\text { 10.1515/jtim-2016-0010 }\end{array}$ \\
\hline Quick Response Code: \\
\hline 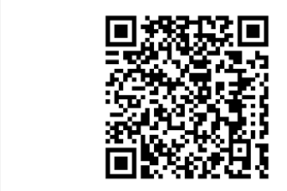 \\
\hline
\end{tabular}

\title{
Corticosteroids, the oldest agent in the prevention of chemotherapy-induced nausea and vomiting: What about the guidelines?
}

\author{
Florence Van Ryckeghem \\ Department of Medical Oncology, Ghent University Hospital, Belgium
}

\section{ABSTRACT}

Chemotherapy-induced nausea and vomiting (CINV) remains one of the most disturbing side effects of cancer treatment. Research in antiemetic therapy has progressed gradually since the early eighties, and the development of antiemetic agents continues. This review focuses on the current management of CINV based on the most recent guidelines, and adherence to the latter is examined more carefully. Setrons (5HT3 receptor antagonists), corticosteroids, and NK-1 receptor antagonists are the cornerstones of antiemetic therapy. Corticosteroids are one of the oldest agents in the prevention of CINV. They are highly effective, increase the effect of other antiemetic agents, and are cost-effective. The latest developed 5HT3 receptor antagonist palonosetron led to an update of the guidelines of CINV. Other types include benzodiazepines, cannabinoids, and olanzapine. Various factors contribute to the overall risk of developing CINV, such as patient characteristics, emetogenic potency of the chemotherapeutic agents, and correct prevention of CINV. Current guidelines determine which is the right preventive regimen for each cancer patient at risk for experiencing CINV. Adherence to these guidelines and implementation in daily practice seem to be below the optimal level. In Belgium, authorities use the guidelines as a base for reimbursement and this has increased the level of implementation.

Key words: antiemetic therapy; chemotherapy; prevention; guidelines

\section{INTRODUCTION}

Chemotherapy-induced nausea and vomiting (CINV) has always been considered one of the most disturbing side effects of chemotherapy by cancer patients. ${ }^{[1]}$ The negative impact on their quality of life is not to be underestimated. ${ }^{[2]}$ However, in a time period of about two decades the number of patients reporting these bothersome side effects has markedly decreased. ${ }^{[3]}$ Better control of side effects has been the result of several steps: a better understanding of the underlying pathophysiologic mechanisms of CINV, the introduction of several new classes of antiemetics based on this knowledge, and last but not least a more correct adherence to international guidelines for the prevention of CINV.
Nevertheless, challenges remain since there is still an important patient population in which prevention of CINV lacks efficacy and satisfaction. This review discusses the current management of CINV and reflects on the situation of adherence to guidelines in Belgium and Europe.

\section{PATHOPHYSIOLOGY OF CINV}

Emesis is the outcome of a process characterized by a vomiting reflex, in humans as well as in the animal species. A displeasing sensation called nausea often occurs prior to the vomiting. The central nervous system plays a critical role in these mechanisms. Historically, one assumed the presence of a central site, a vomiting 
center in se, in the medulla of the brain. We now assume that the anatomic existence of such a site is most unlikely. Instead, the vomiting center consists of a cluster of loosely organized neuronal areas called "the central pattern generator." Incoming afferent pathways mostly originate from two important sources: first, the abdominal vagal afferents and second, the chemoreceptor trigger zone in the area postrema. This area is a circumventricular structure located at the caudal end of the fourth ventricle. Many receptors are located in the terminal field of the abdominal vagal afferents, including 5-hydroxytryptamine3 (5HT3), neurokinin-1 (NK-1), prostaglandin, and cholecystokinin-1 receptors. Opioid and dopaminergic (D2) receptors however, are predominantly found in the chemoreceptor trigger zone. The blood-brain barrier is easily permeable in this site, hence the activation of these receptors by passing molecules such as peptides, chemotherapeutic agents, or their metabolites. Inhibition of the activity of these receptors has been the key to the development of more effective prevention of CINV. Other serotonin, dopamine, and endocannabinoid receptors contribute as well but are far less important to the complex physiopathology of CINV (Figure 1). $\cdot^{[4]}$

\section{RISK FACTORS FOR CINV}

Various factors contribute in a directly proportional manner to the overall risk in developing CINV. These can be divided into three categories: patient characteristics, emetogenic potency of the chemotherapeutic agents, and correct prevention of CINV. Patient variables include gender (greater in females), age (lower at $<6$ years or $>50$ years), alcohol consumption (lower if $>10 \mathrm{U} /$ week), motion sickness, pregnancy-induced emesis, anxiety, and previous cycles of chemotherapy. The emetogenic potential of the given chemotherapy is probably the most important issue: classically the different cytotoxic drugs are divided into four categories based on the probability of provoking a vomiting period, without preventive therapy (Table 1). Table 1 also includes the recently introduced targeted therapy and oral available chemotherapy. It must be stated as well that combination chemotherapy increases the risk for CINV. Finally, attention to the adequate dosage and the known efficacy of the given antiemetic agents can greatly influence the overall risk. ${ }^{[5]}$

\section{TYPES OF CINV}

The concept of acute and delayed emesis arose when antiemetic therapy was first introduced in the early eighties and is based on the typical biphasic curve of CINV in cisplatin treated patients. ${ }^{[6]}$ Acute nausea and vomiting occurs within 24 hours after chemotherapy and is predominantly linked to the 5HT3 receptors. The delayed phase begins after 24 hours, can have a time span of up to 6-7 days, and is more linked to the NK-1 receptors.

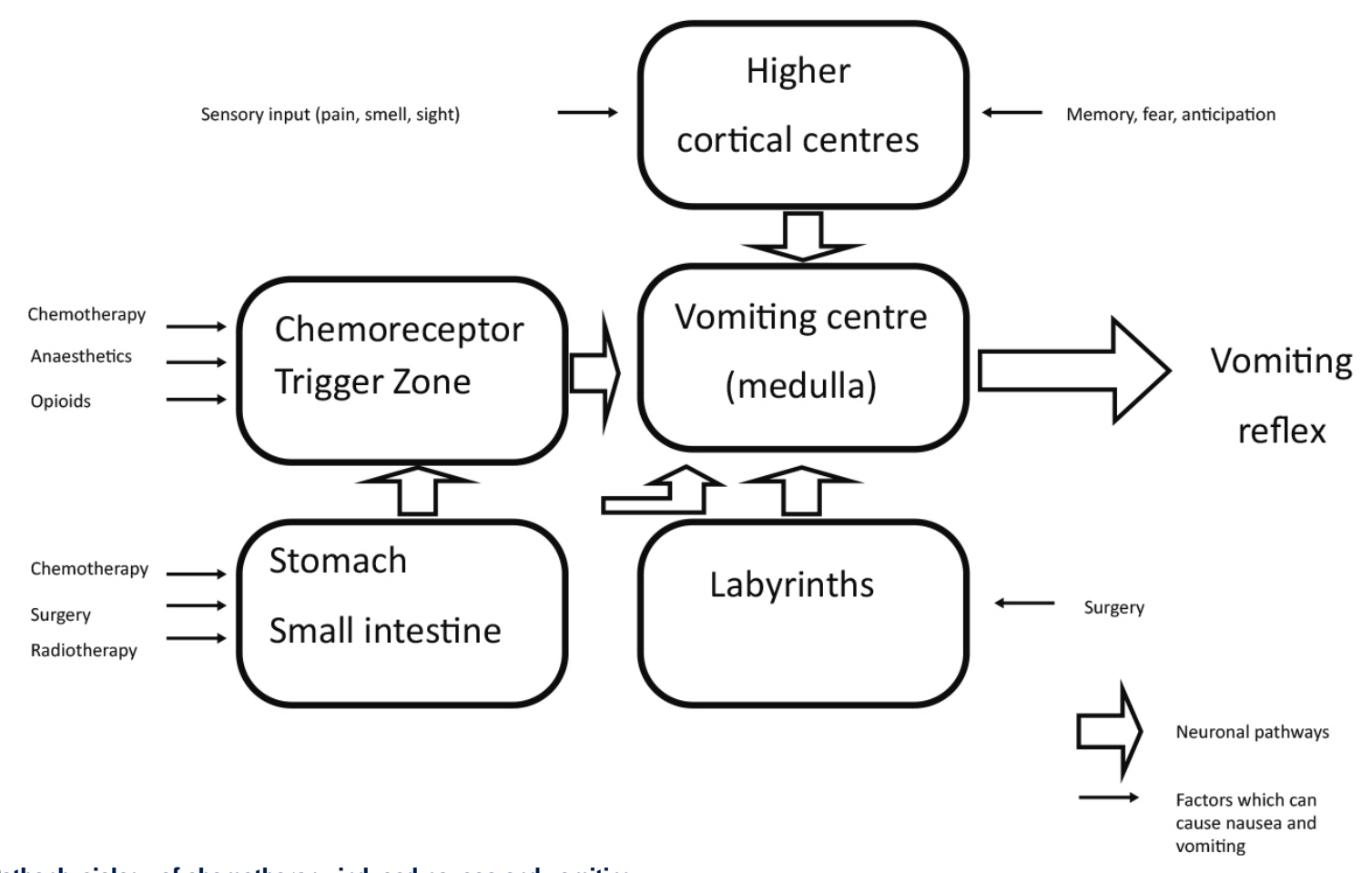

Figure 1: Pathophysiology of chemotherapy-induced nausea and vomiting 
Table 1: Emetogenic potential of single antineoplastic agents

\begin{tabular}{|c|c|c|c|c|}
\hline $\begin{array}{l}\text { Degree of } \\
\text { emetogenicity }\end{array}$ & $\begin{array}{l}\text { High } \\
(>90 \%)\end{array}$ & $\begin{array}{l}\text { Moderate } \\
(30-90 \%)\end{array}$ & $\begin{array}{l}\text { Low } \\
(10-30 \%)\end{array}$ & $\begin{array}{l}\text { Minimal } \\
(<10 \%)\end{array}$ \\
\hline & $\begin{array}{l}\text { Cisplatin } \\
\text { Streptozotocin } \\
\text { Cyclophosphamide } \\
>1500 \mathrm{mg} / \mathrm{m}^{2} \\
\text { Carmustine } \\
\text { Dacarbazine } \\
\text { Procarbazine }\end{array}$ & $\begin{array}{l}\text { Oxaliplatin } \\
\text { Cytarabine } \\
>1 \mathrm{~g} / \mathrm{m}^{2} \\
\text { Carboplatin } \\
\text { Ifosfamide } \\
\text { Cyclophosphamide } \\
<1500 \mathrm{mg} / \mathrm{m}^{2} \\
\text { Doxorubicin } \\
\text { Daunorubicin } \\
\text { Epirubicin } \\
\text { Idarubicin } \\
\text { Irinotecan } \\
\text { Temozolomide } \\
\text { Imatinib }\end{array}$ & $\begin{array}{l}\text { Paclitaxel } \\
\text { Docetaxel } \\
\text { Mitoxantrone } \\
\text { Topotecan } \\
\text { Etoposide } \\
\text { Pemetrexed } \\
\text { Methotrexate } \\
\text { Mitomycine } \\
\text { Gemcitabine } \\
\text { Cytarabine } \\
<100 \mathrm{mg} / \mathrm{m} 2 \\
\text { 5Fluorouracil } \\
\text { Bortezomib } \\
\text { Cetuximab } \\
\text { Trastuzumab } \\
\text { Capecitabine } \\
\text { Fludarabine }\end{array}$ & $\begin{array}{l}\text { Bleomycin } \\
\text { Busulfan } \\
\text { Fludarabine } \\
\text { Vinblastine } \\
\text { Vincristine } \\
\text { Vinorelbine } \\
\text { Bevacizumab } \\
\text { Chlorambucil } \\
\text { Methotrexate } \\
\text { Gefitinib }\end{array}$ \\
\hline
\end{tabular}

This definition is rather relative since evidence emerged, demonstrating that the duration of acute emesis is beyond the first 24 hours, as delayed emesis probably already starts after $8-12$ hours. ${ }^{[7]}$ Other important categories include anticipatory, breakthrough, and refractory emesis. Anticipatory vomiting occurs before, during, or after the initiation of therapy and is a conditioned response linked to various factors associated with previous chemotherapy. Breakthrough emesis arises despite antiemetic prophylaxis and needs rescue medication. Refractory nausea and vomiting occurs when control was incomplete in earlier cycles of treatment. ${ }^{[4]}$

\section{AVAILABLE DRUGS}

The history of antiemetic therapy goes back to the late seventies when high-dose cisplatin was first used in cancer treatment. In order to control the concomitant nausea and vomiting, metoclopramide was administered at very high doses, leading to the observation that this agent, known as a D2 antagonist in low dosage, acted as a 5HT3 receptor antagonist at high doses. This was the critical step to the important discovery of the 5HT3 receptors. Before that period the only available drugs for prevention or treatment of CINV were neuroleptics and steroids. ${ }^{[7]}$

\section{Setrons or 5 HT3 receptor antagonists}

Serotonin is released by enteroendocrine cells in the gastrointestinal tract following administration of cytotoxics. Binding to the 5HT3 receptors (mainly located in the abdominal vagal afferents) kicks off the emetic reflex. Consequently, 5HT3 receptor antagonistic molecules, commonly denominated as setrons, work in an antiemetic mode. Setrons have dramatically changed antiemetic therapy. At present five active drugs exist: ondansetron, tropisetron, granisetron, dolasetron (not available in Belgium), and the more recently developed palonosetron (a so-called second-generation setron). Efficacy is equivalent for all the first-generation setrons, and it is possible to use them interchangeably. ${ }^{[4,8]}$ Furthermore, the outcome of a single-dose regimen is the same as a multiple-dose administration, oral or intravenous. Setrons are usually well tolerated. The most expressed adverse effects are a mild headache, a transient elevation of aminotransferase levels, and constipation. As previously stated, 5HT3 receptor antagonists mainly counteract acute emesis. The effect of setrons on delayed CINV is minimal and this has led to the search for new drugs. ${ }^{[9,10]}$ Palonosetron has a hundred times higher binding affinity and a longer elimination half-life (40 hours). It has an equal effect in comparison to the other setrons on acute emesis but seems to be superior in delayed emesis of moderate emetogenic chemotherapy (MEC). At this moment it is only available as an intravenous drug. ${ }^{[1]}$

\section{Corticosteroids}

Corticosteroids, such as methylprednisolone and dexamethasone, have been part of preventive therapy of CINV since the early eighties. Up until now, the underlying pathophysiologic mechanism of their antiemetic action has remained unclear. Several hypotheses have been formulated, but the only certain effect is a kind of booster effect on other antiemetics. Steroid monotherapy is only used for acute emesis due to the administration of cytotoxic agents with low emetic potential and for delayed emesis following the use of MEC (excluding the combination of an anthracycline and cyclophosphamide). Their efficacy is better known in combination therapy with other antiemetics. ${ }^{[12]}$ Possible adverse effects include insomnia, indigestion, agitation, increased appetite, weight gain, and acne, but these are mainly reported in longterm use. ${ }^{[13]}$ 


\section{NK-1 receptor antagonists}

Substance P has been known for many years to influence several central nervous system pathways. In 1993 it was demonstrated that NK-1 receptor antagonists, blocking the release of substance $\mathrm{P}$, could be candidates for a new class of antiemetic drugs. ${ }^{[14]}$ The first NK-1 receptor antagonist (NK-1 RA) for human use was introduced in 1997. ${ }^{[15]}$ Aprepitant, which is given orally, and its watersoluble prodrug fosaprepitant, given intravenously, are the only marketed drugs of this group at the moment, but several others will soon be registered. ${ }^{[16]}$ One of them is casopitant, which has been proven to be effective for highly emetogenic chemotherapy (HEC) and MEC. ${ }^{[17]}$ The efficacy of NK-1 RA is achieved especially in the delayed phase of CINV. ${ }^{[18-20]}$ The most common side effects of aprepitant are headache, anorexia, diarrhea, hiccups, fatigue, and a mild elevation of serum transaminase levels. ${ }^{[21]}$ Aprepitant is a moderate inhibitor and an inducer of cytochrome P450 (CYP) 3A4, as well as an inducer of CYP2C9. ${ }^{[22]}$ For this reason the dosage of dexamethasone has to be decreased by $50 \%$ when co-administered with aprepitant. Precautions are recommended with the concomitant use of warfarin, as aprepitant induces its metabolism, causing low international normalized ratio values. Interactions with cytotoxic drugs such as docetaxel are clinically negligible. ${ }^{[23]}$ Casopitant is a new NK-1 RA and is metabolized by CYP3A4 as well, but does not induce CYP2C9. Single-dose administration of casopitant on day 1 only, in contrast to the conventional schedule of three days for aprepitant, seems to be equivalent to the 3 -day schedule. ${ }^{[24]}$

\section{Other drugs}

Benzodiazepines reduce anxiety and decrease the risk of anticipatory CINV, but have no major place in the current schedules. Cannabinoids have been investigated for more than 20 years but lack efficacy in preventing emesis at tolerable doses. Their possible side effects such as sedation, euphoria, and hallucinations are usually not desirable for chemotherapy treated patients. ${ }^{[25]}$ Olanzapine, an atypical antipsychotic drug, appeared to be effective in controlling acute and delayed CINV in patients receiving both HEC and MEC, when combined with dexamethasone and palonosetron. Side effects as seen with other antipsychotic drugs jeopardize this promising result. ${ }^{[2]}$

\section{CLINICAL GUIDELINES}

Clinical guidelines and practical recommendations for the prevention of CINV are published and regularly updated by several cancer associations such as Multinational Association of Supportive Care in Cancer (MASCC), European Society for Medical Oncology (ESMO), and American Society of Clinical Oncology (ASCO). Table 2 lists the actual antiemetic guidelines. ${ }^{[27-30]}$ There is a strong degree of concordance between the different guidelines. Triple therapy with a setron, dexamethasone, and an NK-1 receptor antagonist is the regimen of preference for acute emesis due to HEC. Double therapy consisting of a setron and dexamethasone is used as treatment for acute and delayed emesis following administration of agents with MEC, with the exception of the combination anthracycline-cyclophosphamide, which is considered as HEC. At the MASCC meeting in Rome (June 2009), palonosetron was put forward as the setron of choice for MEC. ${ }^{[27-30]}$

As stated before, adherence to guidelines is one of the three risk factors for patients receiving HEC or MEC. Unfortunately, it is known that adherence to and implementation of recommendations are below the optimal level. Several years ago an Italian study revealed surprising results concerning this issue. Strong discrepancies between daily practice and guidelines were observed. More than $20 \%$ of the patients treated with HEC did not receive proper treatment for CINV. That percentage was even higher with patients receiving MEC or low emetogenic chemotherapeutic agents. Moreover, especially in the case of delayed emesis, recommendations were not followed. ${ }^{[31]}$ The reasons for the lack of adherence could be related to the guidelines themselves (for example, too complicated guidelines) or to the corresponding institution (no local guidelines), or to the physician (no knowledge of the guidelines). Education is central to applying correct antiemetic regimens. ${ }^{[32]}$ The effect of proper legislation is another important issue. In countries where reimbursement is rather unlimited, adherence to guidelines seems to be mostly low. ${ }^{[31]}$ If the authorities use the guidelines as a base for reimbursement (which is the case in Belgium), the grade of implementation rises, although there exist a few limitations: the reimbursement of aprepitant has been limited to HEC or AC chemotherapy.

\section{CONCLUSION}

CINV prevention and treatment has progressed gradually over the last 20 years. A few important discoveries stand out on this evolutionary road like 5HT3 receptor antagonists, combination antiemetic therapy, and NK-1 receptor antagonists, but they need the booster effect of corticosteroids. ${ }^{[33]}$ Corticosteroids remain the backbone of antiemetic therapy.

The correct use of the current guidelines for prevention of CINV protects almost $70 \%$ of the patients from this distressing side effect. Despite this knowledge, complete control of nausea and vomiting has not been obtained, highlighting the continuing need for further exploration of the underlying mechanisms and for novel drugs. Emphasis 
Table 2: Guidelines summary of treatment options for chemotherapy-induced nausea and vomiting

\begin{tabular}{|c|c|c|}
\hline Emetic Risk Category & Anti-Emetic Regimen & Belgium (Based on reimbursement) \\
\hline High & $\begin{array}{l}\text { Day 1: } \\
\text { NK-1 antagonist }+ \text { Setron }^{*}+\text { Steroid }^{*} \\
\text { Day } 2 \& 3 \text { : } \\
\text { NK-1 antagonist (only if using aprepitant) }+ \text { Steroid } \\
\text { (ASCO, NCCN recommend continuing steroid on day 4) }\end{array}$ & Setron + Steroid + Aprepitant \\
\hline Moderate & $\begin{array}{l}\text { Day 1: } \\
\text { Setron (palonosetron preferred) + Steroid }+/- \text { NK-1 } \\
\text { antagonist } \\
\text { Day 2\&3: } \\
\text { Setron (if palonosetron was not used) or Steroid or NK-1 } \\
\text { antagonist + Steroid + Setron (for AC) }\end{array}$ & $\begin{array}{l}\text { AC***: } \\
\text { Setron + Steroid + Aprepitant } \\
\text { No AC: } \\
\text { Setron + multiple day steroids }\end{array}$ \\
\hline Low & $\begin{array}{l}\text { Day } 1: \\
\text { Steroid or Setron or Metoclopramide } \\
\text { Day } 2 \& 3 \text { : } \\
\text { No routine prophylaxis }\end{array}$ & Steroid \\
\hline Minimal & No routine prophylaxis & No routine prophylaxis \\
\hline Anticipatory & $\begin{array}{l}\text { Use of best initial therapy }+ \text { behavioural therapy if } \\
\text { needed }+ \text { lorazepam or other benzodiazepines beginning } \\
\text { day }-1\end{array}$ & $\begin{array}{l}\text { Use of best initial therapy }+ \text { behavioural therapy } \\
\text { if needed }+ \text { lorazepam or other benzodiazepines } \\
\text { beginning day }-1\end{array}$ \\
\hline Multiple day regimens & $\begin{array}{l}\text { Day } 1 \text {, day } 2 \& 3 \text { : } \\
\text { Acute management as above. Recommendations based } \\
\text { on risk category }\end{array}$ & $\begin{array}{l}\text { Day } 1 \text {, day } 2 \& 3 \text { : } \\
\text { Acute management as above. Recommendations } \\
\text { based on risk category }\end{array}$ \\
\hline Breakthrough & $\begin{array}{l}\text { Re-evaluate emetogenic risk of regimen } \\
\text { Add } 1 \text { agent from a different drug class to current } \\
\text { regimen } \\
\text { Use medication around the clock, not as needed } \\
\text { Consider adjunctive therapies (Neurokinin antagonists, } \\
\text { Serotonin antagonists, Steroids, Dopamine receptor } \\
\text { antagonists, Cannabinoids, Benzodiazepines, atypical } \\
\text { antipsychotics, antihistamines) }\end{array}$ & $\begin{array}{l}\text { Re-evaluate emetogenic risk of regimen } \\
\text { Add } 1 \text { agent from a different drug class to } \\
\text { current regimen } \\
\text { Use medication around the clock, not as needed } \\
\text { Consider adjunctive therapies (Neurokinin } \\
\text { antagonists, Serotonin antagonists, Steroids, } \\
\text { Dopamine receptor antagonists, Cannabinoids, } \\
\text { Benzodiazepines, atypical antipsychotics, } \\
\text { antihistamines) }\end{array}$ \\
\hline
\end{tabular}

on adherence to the valid guidelines and efforts to educate institutions and physicians can make a great difference in the number of patients still experiencing CINV. Government action in this area is needed and helpful, as the situation in Belgium reflects. Research should continue in order to achieve the ultimate goal of entirely controlling CINV with the most optimal antiemetic therapy.

\section{Conflicts of Interest}

None declared.

\section{REFERENCES}

1. Coates A, Abraham S, Kaye SB, Sowerbutts T, Frewin C, Fox RM, et al. On the receiving end-patient perception of the side-effects of cancer chemotherapy. Eur J Cancer Clin Oncol 1983;19:203-8.

2. Grunberg SM, Deuson RR, Mavros P, Geling O, Hansen M, Cruciani $\mathrm{G}$, et al. Incidence of Chemotherapy induced nausea and emesis after modern antiemetics. Cancer 2004; 100: 2261-2268.

3. Schwartzberg L. Chemotherapy-induced nausea and vomiting: state of the art in 2006. J Support Oncol 2006;4:3-8.

4. Hesketh PJ. Chemotherapy-induced nausea and vomiting. N Engl J Med2008; 358: 2482-94.
5. Schnell FM. Chemotherapy-induced nausea and vomiting: the importance of acute antiemetic control. Oncologist 2003;8:187-98.

6. Kris MG, Gralla RJ, Clark RA, Tyson LB, O'Connell JP, Wertheim MS, et al. Incidence, course, and severity of delayed nausea and vomiting following the administration of high-dose cisplatin. J Clin Oncol 1985;10:1379-84.

7. Hesketh PJ, Van Belle S, Aapro M, Tattersall FD, Naylor RJ, Hargreaves $\mathrm{R}$, et al. Differential involvement of neurotransmitters through the time course of cisplatin-induced emesis as revealed by therapy with specific receptor antagonists. Eur J Cancer 2003;39:1074-80.

8. Del Giglio A, Soares HP, Caparroz C and Castro PC. Granisetron is equivalent to ondansetron for prophylaxis of chemotherapy-induced nausea and vomiting. Cancer 2000;89:2301-8.

9. Geling O, Eichler HG. Should 5 hydroxytryptamine- 3 receptor antagonists be administered beyond 24 hours after chemotherapy to prevent delayed emesis? Systematic re-evaluation of clinical evidence and drug costs implications. J Clin Oncol 2005;23:1289-94.

10. Herstedt J, Koeller JM, Roila F, Hesket PJ, Warr D, Rittenberg C, et al. Acute emesis: moderately emetogenicchemotherapy. Support Care Cancer 2005;13:97-103.

11. Gralla R, Lichinitser M, Van der Vegt S, Sleeboom H, Mezger J, Peschel $\mathrm{C}$, et al. Palonosetron improves prevention of chemotherapyinduced nausea and vomiting following moderately emetogenic chemotherapy: results of a double-blind randomized phase ||| trial comparing single doses of palonosetron with ondansetron. Annal Oncol 2003;14:1570-7. 
12. Grunberg SM. Antiemetic activity in corticosteroids in patients receiving cancer chemotherapy: dosing, efficacy, and tolerability analysis. Ann Oncol 2007; 18: 233-40.

13. Vardy J, Chiew KS, Galica J, Pond GR, Tannock IF. Side effects associated with the use of dexamethasone for prophylaxis of delayed emesis after moderately emetogenic chemotherapy. Br J Cancer 2006;94: 1011-5.

14. Bountra C, Bunce K, Dale T, Gardner C, Jordan C, Twissell D, et al. Antiemetic profile of a non-peptide neurokinin NK1 receptor antagonist, CP-99,994, in ferrets. Eur J Pharmacol 1993;249:R3-4.

15. Kris MG, Radford JE, Pizzo BA, Inabinet R, Hesketh A, Hesketh PJ. Use of an NK1 receptor antagonist to prevent delayed emesis after cisplatin. J Nat Cancer Inst 1997;89:817-8.

16. Van Belle S, Cocquyt V. Fosaprepitant dimeglumine (MK-0517 orL785,298), an intravenous neurokinin-1 antagonist for the prevention of chemotherapy induced nausea and vomiting. Expert Opin Pharmacother 2008;9:1-10.

17. Herrstedt J, Apornwirat W, Shaharyar A, Aziz Z, Roila F, Van Belle S, et al. Phase III results of a novel oral neurokinin-1 (NK-1) receptor antagonist, casopitant: single oral and 3-day oral dosing regimens for chemotherapyinduced nausea and vomiting (CINV) in patients receiving moderately emetogenic chemotherapy (MEC). J Clin Oncol 2009;27:5363-9.

18. Warr DG, Grunberg SM, Gralla RJ, Hesketh PJ, Roila F, Wit RD, et al. The oral NK1 antagonist aprepitant for the prevention of acute and delayed chemotherapy-induced nausea and vomiting: pooled data from 2 randomised, double-blind, placebo controlled trials. Eur J Cancer 2005;41:1278-85.

19. Warr DG, Hesketh PJ, Gralla RJ, Muss HB, Herrstedt J, Eisenberg PD, et al. Efficacy and tolerability of aprepitant for the prevention of chemotherapy-induced nausea and vomiting in patients with breast cancer after moderately emetogenic chemotherapy. J Clin Oncol 2005;23:2822-30.

20. Herstedt J, Muss HB, Warr DG, Hesketh PJ, Eisenberg PD, Raftopoulos $\mathrm{H}$, et al. Efficacy and tolerability of aprepitant for the prevention of chemotherapy-induced nausea and vomiting over multiple cycles of moderately emetogenic chemotherapy. Cancer 2005;104:1548-55.

21. Hesketh PJ, Grunberg SM, Gralla RJ, Warr DG, Roila F, de Wit R, et al. The oral neurokinin-1 receptor antagonist aprepitant for the prevention of chemotherapy-induced nausea and vomiting: a multinational, randomized, double-blind, placebo-controlled trial in patients receiving high-dose cisplatin-The aprepitant protocol 052 study group. J Clin Oncol 2003;21:4112-9.
22. Shadle CR, Lee Y, Majumdar AK, Petty KJ, Gargano C, Bradstreet TE, et al. Evaluation of potential inductive effects of aprepitant on cytochrome P450 3A4 and 2C9 activity. J Clin Pharmacol 2004;44: 215-23.

23. Dando TM and Perry CM. Aprepitant, a review of its use in the prevention of chemotherapy-induced nausea and vomiting. Drugs 2004;64:777-94.

24. Grunberg SM, Rolski J, Strausz J, Aziz Z, Lane S, Russo MW, Wissel P, et al. Efficacy and safety of casopitant mesylate, a neurokinin 1 (NK1)receptor antagonist, in prevention of chemotherapy-induced nausea and vomiting in patients receiving cisplatin-based highly emetogenic chemotherapy: a randomised, doubleblind, placebo-controlled trial. Lancet Oncol 2009;10:549-58.

25. Tramer MR, Carroll D, Campbell FA, Reynolds JM, Moore A, McQuay HJ. Cannabinoids for control of chemotherapy induced nausea and vomiting: quantitative systematic review. BMJ 2001;323:1-8.

26. Navari RM, Einhorn LH, Loehrer PJ, Passik SD, Vinson J, McClean J, et al. A phase II trial of olanzapine, dexamethasone, and palonosetron for the prevention of chemotherapy-induced nausea and vomiting: a Hoosier oncology group study. Support Care Cancer 2007;15:1285-91.

27. Roila F, Herrstadt J, Aaspro M, Gralla RJ, Einhorn LH, Ballatori E, et al. Guideline update for MASCC and ESMO in the prevention of chemotherapy and radiotherapy-induced nausea and vomiting: results of the Perugia consensus conference. Ann Oncol 2010; 21 (Suppl 5): V232-43.

28. Basch E, Prestud AA, Hesketh PJ, Kris MG, Feyer PC, Somerfield MR, et al. Antiemetic: American Society of Clinical Oncology Clinical Practice Guideline Update. J Clin Oncol 2011;29:4189-98.

29. Thompson L \& O’Bryant C, Chemotherapy-induced Nausea \& Vomiting: Guideline summary and clinical challenges. Pharmacy Practice News 2013;40:19-23.

30. Van Ryckeghem F, Van Belle S. Management of chemotherapy induced nausea and vomiting. Acta Clin Belg 2010;65:305-10.

31. Drug Utilization Review Team (DURTO). Antiemetic prescriptions in Italian breast cancer patients submitted to adjuvant chemotherapy. Support Care Cancer 2003;11:785-9.

32. Kaiser R. Antiemetic guidelines: are they being used? Lancet Oncol2005;6:622-5.

34. Navari RM. Antiemetic control: toward a new standard of care for emetogenic chemotherapy. Expert Opin Pharmacother 2009;10:629-44.

How to cite this article: Van Ryckeghem F. Corticosteroids, the oldest agent in the prevention of chemotherapy-induced nausea and vomiting: What about the guidelines? J Transl Intern Med 2016; 4: 46-51. 